\title{
Anger expression and the risk of cardiovascular disease among urban and rural Japanese residents: the Circulatory Risk in Communities Study (CIRCS)
}

Kazuhide Tezuka, MD, Yasuhiko Kubota, MD, PhD, Tetsuya Ohira, MD, PhD, Yuji Shimizu, MD, PhD, Kazumasa Yamagishi, MD, PhD, Mitsumasa Umesawa, MD, PhD, Tomoko Sankai, MD, PhD, Hironori Imano, MD, PhD, Takeo Okada, MD, PhD, Masahiko Kiyama, MD, PhD, and Hiroyasu Iso, MD, PhD: for the CIRCS Investigators

From the Department of Cardiovascular Disease Prevention (Tezuka, Kubota, Shimizu, Okada, Kiyama), Osaka Center for Cancer and Cardiovascular Disease Prevention, Osaka, Japan; Department of Social Medicine (Tezuka, Imano, Iso), Osaka University Graduate School of Medicine, Osaka, Japan; Department of Epidemiology (Ohira), Fukushima Medical University School of Medicine, Fukushima, Japan; Department of Public Health Medicine (Yamagishi, Umesawa, Iso), Faculty of Medicine, and Health Services Research and Development Center

(Yamagishi, Umesawa, Iso), University of Tsukuba, Ibaraki, Japan; Ibaraki Western Medical Center (Yamagishi), Ibaraki, Japan; Department of Public Health (Umesawa), Dokkyo Medical University, Tochigi, Japan; and Department of Public Health and Nursing (Sankai), Faculty of Medicine, University of Tsukuba, Ibaraki, Japan.

Address correspondence to Hiroyasu Iso, MD, PhD, Department of Social Medicine, Osaka University Graduate School of Medicine, 2-2 Yamadaoka, Suita, Osaka 565-0871, Japan; Tel: +816-6879-3911; Fax: +81-6-6879-3919; E-mail: iso@pbhel.med.osaka-u.ac.jp

Word count including the body of the paper, the reference, and the tables: 6,351 
Number of tables: 3

Number of supplementary digital contents: 3 supplementary tables and 2 supplementary figures

Running title: Anger, urbanicity, and cardiovascular disease

Conflicts of Interest and Source of Funding:

This study was supported in part by a Grant-in-Aid for Scientific Research A (22249022) and Research B $(06454234,19390174)$ from the Japan Society for the Promotion of Science. The authors report no conflicts of interest. 
1 Objective: Urbanization, which has been expanding rapidly for the past several decades, has been

2 suggested to increase the risk of cardiovascular disease (CVD) associated with psychological

3 factors such as anger, but the evidence is limited. We examined the hypothesis that urbanicity

4 modifies the association of anger expression with the risk of CVD.

5 Methods: A prospective study was conducted with 5,936 residents of urban and rural communities,

6 aged 40 to 79 , who had completed an annual health checkup including a questionnaire on anger

7 expression between 1995 and 1998. Associations of anger expression with the risk of CVDs were

8 examined using Cox proportional hazards models, after adjusting for classical cardiovascular risk

9 factors.

10 Results: During a median follow-up of 16.6 years, we identified 312 incident CVDs. The mean

11 (standard deviation) of anger expression was 24.7 (5.8) among urban residents and 24.6 (5.7)

12 among rural ones $(\mathrm{p}=.87)$. Among urban residents, anger expression was positively associated

13 with the risk of total CVD: the multivariable hazard ratio (95\% confidence interval) was 1.27 (1.05,

14 1.54). Meanwhile, no association was identified among rural residents: the corresponding ratio

15 (interval) was $0.96(0.85,1.09)$, with a significant interaction between urban and rural residency

16 with anger expression for incident CVD $(\mathrm{p}=.047)$. Similar associations were observed with the

17 risk of CVD subtypes, including ischemic stroke and ischemic cardiovascular disease. 
18 Conclusions: We found a positive association between anger expression and the risk of CVD

19 among urban residents but not rural ones, suggesting that urbanicity enhances the anger-CVD

20 association.

22 Key words: anger expression, urban, rural, cardiovascular disease, ischemic heart disease, stroke.

$24 \mathrm{CVD}=$ cardiovascular disease; IHD $=$ ischemic heart disease; CIRCS $=$ Circulatory Risk in

25 Communities Study; BMI = body mass index; $\mathrm{CT}=$ computed tomography; $\mathrm{MRI}=$ magnetic

26 resonance imaging; $\mathrm{HR}=$ hazard ratio; $\mathrm{CI}=$ confidence interval; $\mathrm{SD}=$ standard deviation; $\mathrm{IL}-6=$

27 interleukin-6; $\mathrm{CBSM}=$ cognitive behavioral stress management. 
30 Urbanization has expanded rapidly for the past several decades. In 2018 , 55\% of the world's

31 population lived in urban areas, compared to $30 \%$ in 1950 . By 2050 , it is projected to grow to $70 \%$

32 (1). Although this dynamic socioenvironmental transition has improved our health condition on

33 average (2), it might have simultaneously increased the risk of some types of diseases and behaviors,

34 particularly mental disorders, sedentary works, and anger (an emotional state of irritation or

35 aggression). A meta-analysis study has demonstrated that the prevalences of mood disorders and

36 anxiety disorders are higher in urban areas than rural ones (3). Sedentary occupations, which might

37 elevate the risk of cardiovascular disease (4), have been suggested to increase with increasing

38 urbanization (5). Anger is highly experienced in urban, mentally disordered, and sedentary people.

39 (6-8).

40 Cardiovascular disease (CVD) is a leading cause of mortality in the world, and its risk can be

41 elevated by several psychological factors, such as depression and anger $(9,10)$. It is suggested that

42 urbanization accompanied by increases in the intake of animal fat and protein, plus the utilization

43 of antihypertensive medication and house heating, has substantially decreased CVD incidence (11).

44 However, urbanicity has been suggested as strengthening the association between depression, a

45 psychological factor, and the CVD risk. A Chinese multi-regional cohort study showed that the 
46 association between depression and the risk of ischemic heart disease (IHD) was pronounced

47 among urban residents but not rural ones (12). The association between anger, another

48 psychological factor, and the risk of CVD could be modified by urbanicity, but no evidence has

49 been made available.

50 Thus, we examined the hypothesis that urbanicity modifies the association of anger expression

51 with the risk of CVD among Japanese residents, using a Japanese multi-regional cohort. Although

52 several measurements of anger/hostility were associated with CVD in Japanese populations $(13,14)$,

53 our previous study measuring anger expression reported that one type of anger expression, "anger-

54 in," was associated with the risk of hypertension in men (15), and thus we used anger expression

55 in the current study.

56

57 METHODS

58 Study Sample

59 The Circulatory Risk in Communities Study (CIRCS) is a multi-regional prospective cohort study

60 for incident CVD in a Japanese community-dwelling population. Details of the CIRCS protocol

61 have been described elsewhere (11,15-17). The participants came from the following 4

62 communities: Yao, Ikawa, Kyowa, and Noichi. We defined Yao as urban, and Ikawa, Kyowa, and 
63 Noichi as rural communities, according to our previous studies (11,15-17). This classification was

64 consistent with previous studies' definitions of an urban city as having more than 100,000

65 inhabitants (18-20), and with the definition of metropolitan areas (central cities and surrounding

66 areas) by the government of Japan. The city of Yao is located next to Osaka City, and is a

67 surrounding area of the Kinki metropolitan area, while Ikawa, Kyowa, and Noichi do not belong

68 to any metropolitan areas (21).

69 The survey population included 6,148 individuals of 40 to 79 years of age living in the

70 communities (1,921 urban and 4,227 rural residents), who had received an annual health checkup

71 including a questionnaire on anger expression in 1997 (Yao), 1996 (Ikawa), or between 1995 and

721998 (Kyowa and Noichi). We excluded participants with missing values on the anger

73 questionnaire $(\mathrm{n}=91)$, those with a history of CVD at baseline $(\mathrm{n}=95)$, or those with incomplete

74 health checkup data $(\mathrm{n}=26)$. Thus, 5,936 participants $(1,877$ urban and 4,059 rural residents $)$ were

75 enrolled in the study. The baseline of this study was defined as the first date when the examination

76 including the questionnaire was completed during the periods.

77 All participants gave their informed consent to participate in the study. The protocol of the

78 study was approved by the institutional review board of the Osaka Center for Cancer and

79 Cardiovascular Disease Prevention (Number: 30-Rinri-15). 


\section{Measurement of anger expression}

82 At baseline, anger expression was measured using the Japanese version of the Spielberger Anger

83 Expression Scale (22). It consisted of eight items from the "anger-in" subscale (holding anger in)

84 and eight items from the "anger-out" subscale (expressing anger outwardly) of the Spielberger

85 scale (23). The anger-in and -out scores were calculated by summing each item score with a four-

86 point Likert scale: one represented the lowest anger expression and four the highest. The scores

87 ranged from 8 to 32 . The total anger expression score was calculated by summing the anger-in and

88 -out scores, ranging from 16 to 64 . We previously reported the validity and reliability of these

89 scales (22). The Cronbach's alpha coefficients for the anger-in, anger-out, and total anger

90 expression scores were $0.77,0.80$, and 0.82 , respectively.

\section{Measurement of CVD risk factors}

93 Smoking status (never, former, or current [more than one cigarette per day]), alcohol intake status

94 (never, former, or current [more than once per week]), and medication status were ascertained by

95 trained interviewers. Body mass index (BMI) was calculated as body weight $(\mathrm{kg}) / \mathrm{height}(\mathrm{m})^{2}$.

96 Systolic and diastolic blood pressure was measured by well-trained observers using standard 
mercury sphygmomanometers on the right arm of seated participants after at least a five-minute

98 rest. The first readings made to the nearest $2 \mathrm{mmHg}$ were used in this study. Serum total cholesterol

99 levels and glucose levels were measured via the enzymatic method using a Hitachi 7250 (Hitachi

100 Medical, Ibaraki, Japan) at the laboratory of the Osaka Medical Center for Health Science and

101 Promotion. Our laboratory's measurement system has met the criteria for precision and accuracy

102 as an international member of the US National Cholesterol Reference Method Laboratory Network

$103(16,17)$.

104 Hypertension was defined as systolic blood pressure of $\geq 140 \mathrm{mmHg}$ and/or diastolic blood

105 pressure of $\geq 90 \mathrm{mmHg}$ and/or the use of antihypertensive medication. Diabetes mellitus was

106 defined as a serum glucose level of $\geq 126 \mathrm{mg} / \mathrm{dL}$ during fasting ( $\geq 8$ hours after meal) and/or $\geq 200$

$107 \mathrm{mg} / \mathrm{dL}$ during non-fasting and/or use of hypoglycemic medication. Hyperlipidemia was defined as

108 serum total cholesterol $\geq 220 \mathrm{mg} / \mathrm{dL}$ and/or use of lipid-lowering medication.

\section{Determination of the endpoint}

111 Information on incident CVD was obtained from national health insurance claims, death

112 certificates, mailed questionnaires, ambulance records, reports by public health nurses and health

113 volunteers, and annual CVD risk surveys. The confirmation of the diagnoses was conducted by 
114 reviewing their medical records at a hospital or clinic and medical histories obtained from all living

115 patients or the deceased's family by telephone or visit $(16,17)$.

116 Incident CVD was defined as IHD or stroke. IHD was composed of sudden cardiac death (death

117 within an hour from the onset of symptoms), myocardial infarction (typical chest pain persisting

118 for at least 30 minutes, unaccompanied obvious non-ischemic cause), and effort angina pectoris

119 (repeated chest pain during effort, disappearing rapidly after cessation of effort), based on the

120 World Health Organization Expert Committee (24). Stroke was determined with the clinical

121 criterion as the rapid onset of a focal neurological disorder that lasted at least 24 hours or until

122 death, and the stroke subtypes (ischemic stroke, intracerebral hemorrhage, subarachnoid

123 hemorrhage, and unclassified stroke) were determined by means of computed tomography (CT),

124 magnetic resonance imaging (MRI), and clinical symptoms. The final diagnosis for incident CVD

125 was determined by a panel of two to four physicians participating in the study blinded to the data

126 from the risk factor survey. Hemorrhagic stroke was defined as intracerebral hemorrhage and

127 subarachnoid hemorrhage. Ischemic CVD was defined as IHD and ischemic stroke.

129 Statistical analyses

130 The participants were followed up until death, CVD events, moving away from the community, or 
131 the end of 2015 in Yao, 2014 in Ikawa, 2013 in Kyowa, and 2009 in Noichi. Hazard ratios (HRs)

132 and $95 \%$ confidence intervals (CIs) for tertiles and a 1-SD increment of the total anger expression

133 score with the risk of total CVD were examined in urban and rural communities using Cox

134 proportional hazards models. The adjustment variables included age, sex, smoking status, alcohol

135 intake status, BMI, hypertension, diabetes mellitus, and hyperlipidemia. The multiplicative

136 interaction of urbanicity with the total anger expression score in relation to the risk of total CVD

137 was tested in the same model. The associations of the total anger expression scale with the risk of

138 CVD subtypes, including IHD, total stroke, ischemic stroke, hemorrhagic stroke, and ischemic

139 CVD, were examined in the same way. Moreover, the procedures were rerun for the subscale scores

140 of anger expression, i.e., anger-in and -out scores. The proportional hazard assumption in the Cox

141 regression was checked using Kaplan-Meier curves and was not violated. In the sex-specific

142 analysis, we found similar trends of association between the total anger expression score and the

143 risk of CVD: the multivariable HR $(95 \% \mathrm{CI})$ was $1.07(0.94,1.22)$ among men and $0.96(0.81$,

144 1.14) among women. Similar associations were observed in the age-specific analysis: the

145 corresponding HR $(95 \%$ CI) was $1.15(0.68,1.93)$ among residents aged 40 to $49,1.07(0.84,1.36)$

146 among those aged 50 to $59,0.98(0.84,1.14)$ among those aged 60 to 69 , and $1.07(0.87,1.32)$

147 among those aged 70 to 79 years. There was no interaction between the sex or age category and 
148 the total anger expression score in relation to the risk of CVD ( $\mathrm{p}$ for interaction $=0.15$ and 0.69 ,

149 respectively). Therefore, we conducted the combined analyses.

150 All statistical tests were two-sided, with $\mathrm{p}<0.05$ regarded as statistically significant. SAS

151 version 9.4 (SAS Institute, Inc., Cary, NC, USA) was used for all statistical analyses.

\section{RESULTS}

154 The baseline characteristics among urban and rural residents are shown in Table 1. Urban

155 participants, compared to rural ones, were more likely to be elderly and female, and had higher

156 means for diastolic blood pressure and serum total cholesterol, higher proportions of

157 hyperlipidemia, lower means for BMI and serum glucose during non-fasting, and lower proportions

158 of current smoking, hypertension, and use of antihypertensive medication. The mean (standard

159 deviation) of the anger-in score was 13.0 (3.8) among urban residents and 13.2 (3.6) among rural

160 ones ( $\mathrm{p}$ for difference $=.005)$, and that of the anger-out score was 11.6 (3.3) among urban ones and

$16111.4(3.2)$ among rural ones ( $\mathrm{p}$ for difference $=.017$ ) (data not shown in the tables).

162 The baseline characteristics according to the tertiles of the total anger expression score among

163 urban and rural residents are shown in Table 2. Both urban and rural residents in the highest tertile

164 of the total anger expression score, compared to the lowest, were more likely to be young and male, 
165 and had higher proportions of current smoking and drinking, lower means for systolic blood

166 pressure, and lower proportions of hypertension and use of antihypertensive medication. Rural

167 residents in the highest tertile had lower means for serum glucose during fasting and serum total

168 cholesterol and lower proportions of hyperlipidemia. The associations of CVD risk factors with

169 anger expression did not differ between urban and rural participants. The baseline characteristics

170 according to the tertiles of the anger-in and -out scores among urban and rural residents are shown

171 in Supplementary Table 1. Similar results were observed in those shown in Table 2.

172 During a median follow-up period of 16.6 years, we identified 312 incident CVDs (76 among

173 urban and 236 among rural residents). The associations of the total anger expression score with the

174 risk of total CVD and CVD subtypes among urban and rural residents are shown in Table 3. Among

175 urban residents, anger expression was positively associated with the risk of total CVD: the

176 multivariable HR $(95 \% \mathrm{CI})$ was $1.27(1.05,1.54)$ for a 1-SD increment of the total anger expression

177 score, while anger expression was not associated with risk among rural residents and the

178 corresponding HR $(95 \% \mathrm{CI})$ was $0.96(0.85,1.09)$. There was a significant interaction between

179 urbanicity and the total anger expression score in relation to the risk of total CVD $(p=.047)$.

180 Similar associations were observed between the total anger expression score and the risk of CVD

181 subtypes; specifically, ischemic stroke and ischemic CVD. We reran the same procedure for the 
183 in Table 3 were observed. We examined the analysis in each rural community separately, and no 184 association of anger expression with the risk of CVD was observed: the multivariable HR (95\%

$185 \mathrm{CI})$ for total CVD according to a 1-SD increment of the total anger expression score was $0.97(0.74$,

186 1.29) in Ikawa, $0.97(0.83,1.13)$ in Kyowa, and $0.73(0.41,1.29)$ in Noichi. We examined the

187 cumulative probability of CVD among urban and rural residents using the Kaplan-Meier methods

188 (Supplementary Figures 1 and 2), and found the associations between tertiles of the total anger

189 expression score and the risk of CVD mostly unchanged over the follow-up period.

\section{DISCUSSION}

192 We compared the association of anger expression with the risk of CVD between urban and rural

193 communities, using a Japanese prospective cohort study. We found that anger expression was

194 associated with an increased risk of CVD among urban residents but not rural ones, and that

195 urbanicity appeared to be an effect modifier for that association. To date, this is the first study to

196 find an urban and rural difference in the association between anger expression and the risk of CVD.

Although at present we cannot determine what factors modified the association, a difference in 
recent experimental study of 25 male volunteers (mean age: 26.1 years) who underwent a

200 functional MRI scan during the Inequality Game, where anger was induced by confronting another

201 player, indicated that anger when seeing a person playing unfairly was associated with increased

202 brain activity in the amygdala $(\mathrm{p}<.05)(25)$. A longitudinal study including 293 male and female

203 patients aged $\geq 30$ years who underwent ${ }^{18} \mathrm{~F}$-fluorodexoyglucose PET/CT and 22 of whom had a

204 CVD event during the median follow-up of 3.7 years showed that amygdalar activity was

205 associated with an increased risk of CVD: the standardized HR $(95 \% \mathrm{CI})=1.59(1.27,1.98)(26)$.

206 Another study of 32 healthy male and female German volunteers (mean age: 43.6 years) dwelling

207 in a city $(n=17)$, town $(n=11)$, or rural area $(n=4)$ revealed that current urban living was

208 associated with increased amygdalar activity in response to acute social stress: the correlation

209 coefficient between current urbanicity and stress-induced amygdalar activity was $0.55(\mathrm{p}<.001)$

210 (18).

211 Amygdalar activation was suggested to elicit an increase in corticosteroid, given that the central

212 and medial nuclei of the amygdala innervate the hypothalamic paraventricular nucleus, which

213 produces a corticotrophin-releasing hormone (27). It was also suggested that excess production of

214 glucocorticoids promotes perivascular inflammation including monocyte and macrophage

215 infiltration and elevated IL-6 via the mineralocorticoid receptors $(28,29)$ and elevates the risk of 
216 CVD (30). A previous study of 72 healthy male and female university students (mean age: 23.2

217 years) showed that an urban upbringing increased the cortisol response to a psychosocial stressor:

218 the correlation coefficient between urbanicity in the first 15 years of life and the cortisol response

219 to the stressor was $0.35(\mathrm{p}=.037)(19)$. Another experimental study of 40 male participants aged

220 between 20 and 40 years who grew up in a city and in the absence of pets $(n=20)$ or on a farm

221 keeping farm animals $(n=20)$ showed that an urban upbringing in the absence of animals, relative

222 to a rural upbringing in the presence of animals, was associated with an increased number of

223 peripheral blood mononuclear cells $(\mathrm{p}=.027)$ and a prolonged increase in plasma IL-6

224 concentrations $(\mathrm{p}=.029)$ following acute psychosocial stress $(20)$. Urbanicity may strengthen the

225 association between anger expression and the risk of CVD via inflammatory pathways, which

226 partially explains our finding among urban residents that anger expression was positively

227 associated with the risk of ischemic stroke and ischemic CVD.

228 Moreover, a difference in the amount of nature contacts between urban and rural residents

229 might be involved in the modification by urbanicity. An American study of 120 undergraduate male

230 and female volunteers who first viewed a stressful film (depicting several serious injuries in a

231 woodworking shop, with simulated blood and mutilation) and were then exposed to a video of

232 either a natural $(n=40)$ or urban environment $(n=80)$ showed a larger decline in the 
233 anger/aggression level after the film among participants exposed to the natural setting, compared

234 to those exposed to the urban one (31). A similar study in the Netherlands on 106 men and women

235 (mean age: 21.9 years) who first viewed stressful fragments of a movie (including a farmer's wife

236 decapitating a rooster, etc.) and then were exposed to a video representing walks through either

237 natural or urban environments found that participants who viewed natural environments, compared

238 to those who viewed urban ones, showed greater restoration of their anger level (32). An imaging

239 study of 38 male and female volunteers (mean age: 26.6 years) who underwent MRI scanning and

240 were assigned to a 90-min walk in either a natural environment $(n=19)$ or an urban one $(n=19)$

241 showed that a nature experience, compared to an urban experience, led to greater reduction in the

242 activation of the subgenual prefrontal cortex (33), a part of the rostral cingulate (34), which was

243 activated by increased activity of the amygdala (35). Thus, nature experiences may suppress rostral

244 cingulate activity through reduced activity in the amygdala, and that reduction in amygdalar

245 activity may be associated with a decreased risk of CVD.

246 Cognitive behavioral stress management (CBSM) training, which was suggested to decrease

247 anger/aggression (36-38), reduced mortality and recurrent CVD in coronary heart disease patients

248 hospitalized at urban Swedish clinics $(39,40)$. Although the effect of CBSM training remains to be

249 explored in the primary prevention of CVD, the training might be useful for some urban residents 
with high levels of anger expression.

251 We observed similar associations of anger-in and -out with the risk of CVD in urban and rural

252 populations (Supplementary Tables 2 and 3). Although the pathological role of anger-in and -out

253 should be different in part, our results found no obvious difference between anger-in and -out in

254 relation to the risk of CVD among urban and rural residents.

255 The strengths of our study include the systematic diagnosis of incident CVD by a panel of

256 physicians blinded to the data from the risk factor survey. The diagnosis criteria common to all

257 communities enabled us to compare the risk of CVD associated with anger expression between

258 urban and rural residents.

259 The study also has a few limitations. First, because the number of CVD events was relatively

260 small, we could not fully discuss the association between anger expression and the risk of CVD

261 subtypes. Second, we did not have data for psychosocial factors that may confound the association

262 between anger expression and the risk of CVD, such as childhood socioeconomic status (41),

263 mismatch in spouses' anger-coping response styles (42), and motive profiles, including agonistic

264 strivings (43). Last, as only one urban community (Yao city) was recruited in our study, further

265 studies including other urban communities should evaluate the external validity of our results.

266 In conclusion, we found a positive association of anger expression with the risk of CVD among 
267 urban residents but not rural ones. Factors more often seen in rural than urban communities might

268 offset the CVD risk associated with anger expression, and thus, future studies will need to clarify

269 those factors.

270

271 


\section{ACKNOWLEDGEMENTS}

273 The CIRCS Investigators are: Takeo Okada, Yuji Shimizu, Yasuhiko Kubota, Shinichi Sato, Mina

274 Hayama-Terada and Masahiko Kiyama, Osaka Center for Cancer and Cardiovascular Disease

275 Prevention; Hironori Imano, Renzhe Cui, Isao Muraki, Akihiko Kitamura, Hiroshige Jinnouchi,

276 Mizuki Sata and Hiroyasu Iso, Osaka University; Kazumasa Yamagishi, Mitsumasa Umesawa and

277 Tomoko Sankai, University of Tsukuba; Koutatsu Maruyama, Ehime University; Ai Ikeda and

278 Takeshi Tanigawa, Juntendo University, and Masanori Nagao and Tetsuya Ohira, Fukushima

279 Medical University.

280 We want to thank Professor Emeritus Yoshio Komachi (University of Tsukuba), Professor

281 Emeritus Hideki Ozawa (Medical College of Oita), Former Professor Minoru Iida (Kansai

282 University of Welfare Sciences), the Late Professor Emeritus Takashi Shimamoto (University of

283 Tsukuba), the Late Professor Emeritus Masamistu Konishi (Ehime University), Dr Yoshinori

284 Ishikawa (Consultant of Osaka Center for Cancer and Cardiovascular Disease Prevention),

285 Professor Yoshihiko Naito (Mukogawa Women's University), and Professor Tomonori Okamura

286 (Keio University), for their support in conducting the long-term cohort studies. The authors also

287 thank the research staff in the Osaka Center for Cancer and Cardiovascular Disease Prevention and

288 health professionals in the survey communities for their valuable assistance and for their expert 
289 help.

290 Conflicts of Interest and Source of Funding: This study was supported in part by a Grant-in-

291 Aid for Scientific Research A (22249022) and Research B (06454234, 19390174) from the Japan

292 Society for the Promotion of Science. The authors report no conflicts of interest.

293 


\section{REFERENCES}

295 1. United Nations, Department of economic and social affairs, Population division. World

296 urbanization prospects: the 2018 revision, key facts. New York: United Nations; 2018.

297 Available at: https://population.un.org/wup/Publications/Files/WUP2018-KeyFacts.pdf.

$298 \quad$ Accessed 10 Jul 2019.

299 2. Dye C. Health and urban living. Science 2008;319:766-9.

300 3. Peen J, Schoevers RA, Beekman AT, Dekker J. The current status of urban-rural differences

301 in psychiatric disorders. Acta Psychiatr Scand 2010;121:84-93.

302 4. Warren TY, Barry V, Hooker SP, Sui X, Church TS, Blair SN. Sedentary behaviors increase

303 risk of cardiovascular disease mortality in men. Med Sci Sports Exerc 2010;42:879-85.

304 5. Monda KL, Gordon-Larsen P, Stevens J, Popkin BM. China's transition: the effect of rapid

305 urbanization on adult occupational physical activity. Soc Sci Med 2007;64:858-70.

306 6. Judd LL, Schettler PJ, Coryell W, Akiskal HS, Fiedorowicz JG. Overt irritability/anger in

307 unipolar major depressive episodes: past and current characteristics and implications for

308 long-term course. JAMA Psychiatry 2013;70:1171-80.

309 7. Dey B, Rahman A, Bairagi A, Roy K. Stress and anger of rural and urban adolescents.

$310 \quad$ Psychology 2014;5:177-84. 
311 8. Ellingson LD, Meyer JD, Shook RP, Dixon PM, Hand GA, Wirth MD, Paluch AE, Burgess

312 S, Hebert JR, Blair SN. Changes in sedentary time are associated with changes in mental

313 wellbeing over 1 year in young adults. Prev Med Rep 2018;11:274-81.

314 9. Hare DL, Toukhsati SR, Johansson P, Jaarsma T. Depression and cardiovascular disease: a

315 clinical review. Eur Heart J 2014;35:1365-72.

316 10. Chida Y, Steptoe A. The association of anger and hostility with future coronary heart disease: a meta-analytic review of prospective evidence. J Am Coll Cardiol 2009;53:936-46.

11. Iida M. Seikatsu shūkan no henka ga junkanki shikkan no hassei, shinten ni oyobosu eikyō ni tuite no kentō [Effects of environmental and behavioral changes on the incidence and progression of cardiovascular disease]. Seijinbyō no kenkyū 1977;6:113-20 (in Japanese). Study. J Am Heart Assoc 2016;5:e004687. Japanese. J Epidemiol 2001;11:243-8. 
14. Izawa S, Eto Y, Yamada KC, Nakano M, Yamada H, Nagayama M, Kikuchi T, Nomura S.

Cynical hostility, anger expression style, and acute myocardial infarction in middle-aged Japanese men. Behav Med 2011;37:81-6.

15. Ohira T, Iso H, Tanigawa T, Imano H, Kitamura A, Sato S, Naito Y, Shimamoto T. Prospective study of depressive symptoms, anger expression, and anxiety with

16. Iso H, Sato S, Kitamura A, Imano H, Kiyama M, Yamagishi K, Cui R, Tanigawa T, cardiovascular diseases among Japanese. Jpn J Psychosom Med 2004;44:335-41 (in

17. Yamagishi K, Muraki I, Kubota Y, Hayama-Terada M, Imano H, Cui R, Umesawa M, Japanese).

Shimamoto T. Metabolic syndrome and the risk of ischemic heart disease and stroke among Japanese men and women. Stroke 2007;38:1744-51. in Communities Study (CIRCS): A long-term epidemiological study for lifestyle-related disease among Japanese men and women living in communities. J Epidemiol 2019;29:83-91. neural social stress processing in humans. Nature 2011;474:498-501. 
345 19. Steinheuser V, Ackermann K, Schönfeld P, Schwabe L. Stress and the city: impact of urban

346 upbringing on the (re)activity of the hypothalamus-pituitary-adrenal axis. Psychosom Med

$347 \quad 2014 ; 76: 678-85$.

348 20. Böbel TS, Hackl SB, Langgartner D, Jarczok MN, Rohleder N, Rook GA, Lowry CA,

349 Gündel H, Waller C, Reber SO. Less immune activation following social stress in rural vs.

350 urban participants raised with regular or no animal contact, respectively. Proc Natl Acad Sci

$351 \quad$ U S A 2018;115:5259-64.

352 21. Statistics bureau, Ministry of internal affairs and communications, the government of Japan.

353 Names of shi, machi and mura of major metropolitan areas. Available at: http://www.stat.go.jp/english/data/jyutaku/pdf/25daitoshi.pdf. Accessed 10 Jul 2019.

22. Ohira T, Iso H, Tanigawa T, Sankai T, Imano H, Okamura T, Kiyama M, Kitamura A, version of the selected anger expression scale and age, sex, occupation and regional differences in anger expression among Japanese. J Epidemiol 2000;10:118-23. 
MA, Rosenman RH, editors. Anger and hostility in cardiovascular and behavioral disorders. New York: Hemisphere/McGraw Hill; 1985. p. 5-30.

24. WHO Expert Committee. Arterial hypertension and ischemic heart disease, preventive aspect. Geneva: World Health Organization; 1962 (WHO technical report series no. 231).

25. Klimecki OM, Sander D, Vuilleumier P. Distinct brain areas involved in anger versus punishment during social interactions. Sci Rep 2018;8:10556.

26. Tawakol A, Ishai A, Takx RA, Figueroa AL, Ali A, Kaiser Y, Truong QA, Solomon CJ, events: a longitudinal and cohort study. Lancet 2017;389:834-45.

27. Jankord R, Herman JP. Limbic regulation of hypothalamo-pituitary-adrenocortical function vascular inflammation. Heart Fail Rev 2005;10:31-7.

29. Walker BR. Glucocorticoids and cardiovascular disease. Eur J Endocrinol 2007;157:545-59.

30. Wei L, MacDonald TM, Walker BR. Taking glucocorticoids by prescription is associated with subsequent cardiovascular disease. Ann Intern Med 2004;141:764-70. 
378 31. Ulrich RS, Simons RF, Losito BD, Fiorito E, Miles MA, Zelson M. Stress recovery during

379 exposure to natural and urban environments. J Environ Psychol 1991;11:201-30.

380 32. van den Berg AE, Koole SL, van der Wulp NY. Environmental preference and restoration:

381 (How) are they related? J Environ Psychol 2003;23:135-46.

382 33. Bratman GN, Hamilton JP, Hahn KS, Daily GC, Gross JJ. Nature experience reduces

383 rumination and subgenual prefrontal cortex activation. Proc Natl Acad Sci U S A

$384 \quad 2015 ; 112: 8567-72$.

385 34. Stevens FL, Hurley RA, Taber KH. Anterior cingulate cortex: unique role in cognition and emotion. J Neuropsychiatry Clin Neurosci 2011;23:121-5.

387 35. Etkin A, Egner T, Peraza DM, Kandel ER, Hirsch J. Resolving emotional conflict: a role for

388 the rostral anterior cingulate cortex in modulating activity in the amygdala. Neuron 2006;51:871-82. 
393 37. Chen C, Li C, Wang H, Ou JJ, Zhou JS, Wang XP. Cognitive behavioral therapy to reduce

394 overt aggression behavior in Chinese young male violent offenders. Aggress Behav

$395 \quad 2014 ; 40: 329-36$.

396 38. Bishop GD, Kaur D, Tan VL, Chua YL, Liew SM, Mak KH. Effects of a psychosocial skills

397 training workshop on psychophysiological and psychosocial risk in patients undergoing

398 coronary artery bypass grafting. Am Heart J 2005;150:602-9.

399 39. Orth-Gomér K, Schneiderman N, Wang HX, Walldin C, Blom M, Jernberg T. Stress

400 reduction prolongs life in women with coronary disease: the Stockholm Women's

401 Intervention Trial for Coronary Heart Disease (SWITCHD). Circ Cardiovasc Qual Outcomes

$402 \quad 2009 ; 2: 25-32$.

403 40. Gulliksson M, Burell G, Vessby B, Lundin L, Toss H, Svärdsudd K. Randomized controlled

404 trial of cognitive behavioral therapy vs standard treatment to prevent recurrent cardiovascular

405 events in patients with coronary heart disease: Secondary Prevention in Uppsala Primary

$406 \quad$ Health Care project (SUPRIM). Arch Intern Med 2011;171:134-40.

407 41. Merjonen P, Pulkki-Råback L, Puttonen S, Keskivaara P, Juonala M, Telama R, Viikari J,

408 Raitakari OT, Keltikangas-Järvinen L. Anger is associated with subclinical atherosclerosis in 

Study. J Behav Med 2008;31:35-44.

42. Bourassa KJ, Sbarra DA, Ruiz JM, Karciroti N, Harburg E. Mismatch in spouses' angercoping response styles and risk of early mortality: A 32-year follow-up study. Psychosom Med 2019;81:26-33. association between cortisol and high blood pressure. Psychosom Med 2017;79:416-25. 
417 List of Supplemental Digital Content:

418 Supplementary Tables 20191010.xlsx

419 Supplementary Figure 1 20191010.docx

420 Supplementary Figure 2 20191010.docx 
Table 1 Baseline characteristics among urban and rural residents.

\begin{tabular}{|c|c|c|c|}
\hline & Urban & Rural & $\mathrm{p}$ for difference ${ }^{\mathrm{a}}$ \\
\hline Number of participants & 1877 & 4059 & \\
\hline Age (year), mean (SD) & $58.3(9.4)$ & $56.9(8.9)$ & $<.001$ \\
\hline Men, n (\%) & $560(29.8)$ & $1594(39.3)$ & $<.001$ \\
\hline Total anger expression score, mean (SD) & $24.7(5.8)$ & $24.6(5.7)$ & .87 \\
\hline Body mass index $\left(\mathrm{kg} / \mathrm{m}^{2}\right)$, mean $(\mathrm{SD})$ & $23.0(3.0)$ & $23.6(3.1)$ & $<.001$ \\
\hline Current smoking, n (\%) & $350(18.7)$ & $894(22.0)$ & .003 \\
\hline Current drinking, $\mathrm{n}(\%)$ & $648(34.5)$ & $1452(35.8)$ & .35 \\
\hline Hypertension, n (\%) & $809(43.1)$ & $1898(46.8)$ & .009 \\
\hline Systolic blood pressure (mmHg), mean (SD) & $135.0(20.4)$ & $134.4(19.9)$ & .46 \\
\hline Diastolic blood pressure (mmHg), mean (SD) & $81.7(11.2)$ & $80.7(11.7)$ & .005 \\
\hline Use of antihypertensive medication, $\mathrm{n}(\%)$ & $261(13.9)$ & $713(17.6)$ & $<.001$ \\
\hline Diabetes mellitus, $\mathrm{n}(\%)$ & $77(4.1)$ & $206(5.1)$ & .10 \\
\hline Serum glucose during fasting $(\mathrm{mg} / \mathrm{dL})$, mean $(\mathrm{SD})$ & $100.0(18.3)$ & $99.1(19.0)$ & .053 \\
\hline Serum glucose during non-fasting (mg/dL), mean (SD) & $100.8(28.5)$ & $113.7(39.2)$ & $<.001$ \\
\hline Use of hypoglycemic medication, $\mathrm{n}(\%)$ & $31(1.7)$ & $94(2.3)$ & .097 \\
\hline Hyperlipidemia, n (\%) & $861(45.9)$ & $1387(34.2)$ & $<.001$ \\
\hline Serum total cholesterol (mg/dL), mean (SD) & $216.0(35.5)$ & $204.5(35.4)$ & $<.001$ \\
\hline Use of lipid-lowering medication, $\mathrm{n}(\%)$ & $99(5.3)$ & $207(5.1)$ & .78 \\
\hline
\end{tabular}

a Obtained from wilcoxon rank sum tests for numeric values and chi-squared tests for categorical values. 
Table 2 Baseline characteristics among urban and rural residents according to tertiles $(\mathrm{T})$ of total anger expression score.

\begin{tabular}{|c|c|c|c|c|c|c|c|c|}
\hline & \multicolumn{4}{|c|}{ Urban } & \multicolumn{4}{|c|}{ Rural } \\
\hline & $\begin{array}{c}\mathrm{T} 1 \\
\text { (Scores 16-21) } \\
\end{array}$ & $\begin{array}{c}\mathrm{T} 2 \\
\text { (Scores 22-27) } \\
\end{array}$ & $\begin{array}{c}\mathrm{T} 3 \\
(\text { Scores } 28-56) \\
\end{array}$ & $\mathrm{p}$ for trend ${ }^{\mathrm{a}}$ & $\begin{array}{c}\mathrm{T} 1 \\
\text { (Scores 16-21) } \\
\end{array}$ & $\begin{array}{c}\mathrm{T} 2 \\
(\text { Scores } 22-27) \\
\end{array}$ & $\begin{array}{c}\mathrm{T} 3 \\
(\text { Scores } 28-63) \\
\end{array}$ & $\mathrm{p}$ for trend ${ }^{\mathrm{a}}$ \\
\hline Number of participants & 610 & 730 & 537 & & 1329 & 1615 & 1115 & \\
\hline Age (year), mean (SD) & $61.9(9.0)$ & $57.0(9.2)$ & $55.8(8.8)$ & $<.001$ & $59.8(8.4)$ & $55.9(8.8)$ & $55.1(8.9)$ & $<.001$ \\
\hline Men, n (\%) & $173(28.4)$ & $204(28.0)$ & $183(34.1)$ & .040 & $513(38.6)$ & $573(35.5)$ & $508(45.6)$ & .001 \\
\hline Body mass index $\left(\mathrm{kg} / \mathrm{m}^{2}\right)$, mean $(\mathrm{SD})$ & $23.0(3.1)$ & $22.9(2.9)$ & $22.9(2.9)$ & .80 & $23.5(3.2)$ & $23.6(3.2)$ & $23.6(2.9)$ & .19 \\
\hline Current smoking, n (\%) & $105(17.2)$ & $116(15.9)$ & $129(24.0)$ & .004 & $274(20.6)$ & $332(20.6)$ & $288(25.8)$ & .003 \\
\hline Current drinking, $\mathrm{n}(\%)$ & $189(31.0)$ & $241(33.0)$ & $218(40.6)$ & .001 & $425(32.0)$ & 547 (33.9) & $480(43.1)$ & $<.001$ \\
\hline Hypertension, n (\%) & $300(49.2)$ & $292(40.0)$ & $217(40.4)$ & .002 & $678(51.0)$ & $736(45.6)$ & $484(43.4)$ & $<.001$ \\
\hline Systolic blood pressure (mmHg), mean (SD) & $138.0(21.3)$ & $133.9(20.2)$ & $133.3(19.3)$ & $<.001$ & $136.5(20.1)$ & $133.7(19.8)$ & $132.9(19.8)$ & $<.001$ \\
\hline Diastolic blood pressure (mmHg), mean (SD) & $81.8(11.1)$ & $81.2(11.5)$ & $82.4(10.9)$ & .38 & $80.8(11.8)$ & $80.4(11.7)$ & $81.0(11.7)$ & .65 \\
\hline Use of antihypertensive medication, $\mathrm{n}(\%)$ & $104(17.1)$ & $93(12.7)$ & $64(11.9)$ & .011 & $280(21.1)$ & $269(16.7)$ & $164(14.7)$ & $<.001$ \\
\hline Diabetes mellitus, n (\%) & $28(4.6)$ & $23(3.2)$ & $26(4.8)$ & .88 & $70(5.3)$ & $77(4.8)$ & $59(5.3)$ & .99 \\
\hline Serum glucose during fasting $(\mathrm{mg} / \mathrm{dL})$, mean $(\mathrm{SD})$ & $101.4(18.9)$ & $99.3(18.9)$ & $99.4(17.0)$ & .16 & $102.0(26.4)$ & $98.4(17.7)$ & $97.8(13.2)$ & .033 \\
\hline Serum glucose during non-fasting $(\mathrm{mg} / \mathrm{dL})$, mean $(\mathrm{SD})$ & $99.9(19.9)$ & $101.3(32.0)$ & $101.0(32.1)$ & .67 & $115.4(41.4)$ & $112.5(35.8)$ & $113.3(41.1)$ & .18 \\
\hline Use of hypoglycemic medication, $\mathrm{n}(\%)$ & $9(1.5)$ & $9(1.2)$ & $13(2.4)$ & .23 & $35(2.6)$ & $31(1.9)$ & $28(2.5)$ & .78 \\
\hline Hyperlipidemia, n (\%) & $296(48.5)$ & $324(44.4)$ & $241(44.9)$ & .20 & $478(36.0)$ & $553(34.2)$ & $356(31.9)$ & .037 \\
\hline Serum total cholesterol (mg/dL), mean (SD) & $217.8(35.5)$ & $214.9(34.6)$ & $215.2(36.6)$ & .21 & $206.2(34.9)$ & $204.2(35.3)$ & $202.9(36.0)$ & .024 \\
\hline Use of lipid-lowering medication, $\mathrm{n}(\%)$ & $38(6.2)$ & $39(5.3)$ & $22(4.1)$ & .11 & $75(5.6)$ & $86(5.3)$ & $46(4.1)$ & .096 \\
\hline
\end{tabular}

a Obtained from linear regression analyses. 


\begin{tabular}{|c|c|c|c|c|c|c|c|c|c|c|c|}
\hline & \multicolumn{5}{|c|}{ Urban } & \multicolumn{5}{|c|}{ Rural } & \multirow[b]{2}{*}{$\mathrm{p}$ for interaction ${ }^{\mathrm{c}}$} \\
\hline & $\begin{array}{c}\mathrm{T} 1 \\
\text { (Scores 16-21) }\end{array}$ & $\begin{array}{c}\mathrm{T} 2 \\
\text { (Scores 22-27) }\end{array}$ & $\begin{array}{c}\mathrm{T} 3 \\
\text { (Scores 28-56) }\end{array}$ & $p$ for trend & 1-SD increment & $\begin{array}{c}\mathrm{T} 1 \\
\text { (Scores 16-21) }\end{array}$ & $\begin{array}{c}\mathrm{T} 2 \\
\text { (Scores 22-27) }\end{array}$ & $\begin{array}{c}\mathrm{T3} \\
\text { (Scores 28-63) }\end{array}$ & $p$ for trend & 1-SD increment & \\
\hline Person-years & 9631 & 12075 & 8842 & & 30549 & 18490 & 23678 & 16469 & & 58636 & \\
\hline \multicolumn{12}{|l|}{ Total cardiovascular disease } \\
\hline No. of cases & 22 & 32 & 22 & & 76 & 87 & 93 & 56 & & 236 & \\
\hline $\begin{array}{l}\text { Age- and sex-adjusted HRs }(95 \% \mathrm{CIs})^{\mathrm{a}} \\
\text { p-value }\end{array}$ & 1 (reference) & $\begin{array}{c}1.76(1.02,3.05) \\
.044\end{array}$ & $\begin{array}{c}1.87(1.02,3.42) \\
.044\end{array}$ & .028 & $\begin{array}{c}1.28(1.05,1.55) \\
.014\end{array}$ & 1 (reference) & $\begin{array}{c}1.10(0.82,1.47) \\
.53\end{array}$ & $\begin{array}{c}0.95(0.68,1.33) \\
.75\end{array}$ & .83 & $\begin{array}{c}0.96(0.84,1.08) \\
.48\end{array}$ & .039 \\
\hline $\begin{array}{l}\text { Multivariable-adjusted HRs }(95 \% \mathrm{CIs})^{\mathrm{a}, \mathrm{b}} \\
\text { p-value }\end{array}$ & 1 (reference) & $\begin{array}{c}1.81(1.04,3.13) \\
.036\end{array}$ & $\begin{array}{c}1.87(1.02,3.42) \\
.044\end{array}$ & . 027 & $\begin{array}{c}1.27(1.05,1.54) \\
.015\end{array}$ & 1 (reference) & $\begin{array}{c}1.07(0.79,1.43) \\
\quad .67\end{array}$ & $\begin{array}{c}0.96(0.68,1.34) \\
.79\end{array}$ & .85 & $\begin{array}{c}0.96(0.85,1.09) \\
.53\end{array}$ & .047 \\
\hline \multicolumn{12}{|l|}{ Ischemic heart disease } \\
\hline No. of cases & 4 & 10 & 6 & & 20 & 19 & 20 & 13 & & 52 & \\
\hline $\begin{array}{l}\text { Age- and sex-adjusted HRs }(95 \% \mathrm{CIs})^{\mathrm{a}} \\
\text { p-value }\end{array}$ & 1 (reference) & $\begin{array}{c}2.61(0.82,8.35) \\
.11\end{array}$ & $\begin{array}{c}2.20(0.63,7.72) \\
.22\end{array}$ & .16 & $\begin{array}{c}1.37(0.94,2.00) \\
.10\end{array}$ & 1 (reference) & $\begin{array}{c}1.04(0.55,1.98) \\
.90\end{array}$ & $\begin{array}{c}0.91(0.44,1.87) \\
.79\end{array}$ & .81 & $\begin{array}{c}0.88(0.64,1.21) \\
.44\end{array}$ & .093 \\
\hline $\begin{array}{l}\text { Multivariable-adjusted HRs }(95 \% \mathrm{CIs})^{\mathrm{a}, \mathrm{b}} \\
\text { p-value }\end{array}$ & 1 (reference) & $\begin{array}{c}2.40(0.76,7.63) \\
.14\end{array}$ & $\begin{array}{c}2.06(0.57,7.45) \\
.27\end{array}$ & .23 & $\begin{array}{c}1.33(0.88,2.00) \\
.18\end{array}$ & 1 (reference) & $\begin{array}{l}0.97(0.51,1.85) \\
.93\end{array}$ & $\begin{array}{c}0.91(0.44,1.90) \\
.80\end{array}$ & .80 & $\begin{array}{c}0.88(0.63,1.23) \\
.46\end{array}$ & .12 \\
\hline \multicolumn{12}{|l|}{ Total stroke } \\
\hline No. of cases & 18 & 22 & 16 & & 56 & 68 & 73 & 43 & & 184 & \\
\hline $\begin{array}{l}\text { Age- and sex-adjusted HRs }(95 \% \mathrm{CIs})^{\mathrm{a}} \\
\text { p-value }\end{array}$ & 1 (reference) & $\begin{array}{c}1.55(0.82,2.91) \\
.18\end{array}$ & $\begin{array}{c}1.79(0.90,3.59) \\
.098\end{array}$ & . 079 & $\begin{array}{c}1.24(0.99,1.56) \\
.060\end{array}$ & 1 (reference) & $\begin{array}{c}1.12(0.80,1.55) \\
.52\end{array}$ & $\begin{array}{c}0.96(0.66,1.40) \\
.83\end{array}$ & .91 & $\begin{array}{c}0.98(0.86,1.12) \\
.75\end{array}$ & .18 \\
\hline $\begin{array}{l}\text { Multivariable-adjusted HRs }(95 \% \text { CIs })^{\text {a,b }} \\
\text { p-value }\end{array}$ & 1 (reference) & $\begin{array}{c}1.63(0.87,3.07) \\
.13\end{array}$ & $\begin{array}{c}1.80(0.90,3.60) \\
.098\end{array}$ & .074 & $\begin{array}{c}1.24(0.99,1.55) \\
.061\end{array}$ & 1 (reference) & $\begin{array}{c}1.09(0.78,1.52) \\
.61\end{array}$ & $\begin{array}{c}0.97(0.66,1.42) \\
.86\end{array}$ & .93 & $\begin{array}{c}0.98(0.86,1.12) \\
.80\end{array}$ & .21 \\
\hline \multicolumn{12}{|l|}{ Ischemic stroke } \\
\hline No. of cases & 7 & 15 & 12 & & 34 & 49 & 41 & 27 & & 117 & \\
\hline $\begin{array}{l}\text { Age- and sex-adjusted HRs }(95 \% \mathrm{CIs})^{\mathrm{a}} \\
\text { p-value }\end{array}$ & 1 (reference) & $\begin{array}{c}2.67(1.09,6.57) \\
.032\end{array}$ & $\begin{array}{c}3.30(1.29,8.48) \\
.013\end{array}$ & .006 & $\begin{array}{c}1.45(1.12,1.86) \\
.004\end{array}$ & 1 (reference) & $\begin{array}{c}0.89(0.59,1.36) \\
.60\end{array}$ & $\begin{array}{c}0.86(0.54,1.38) \\
.53\end{array}$ & .51 & $\begin{array}{c}0.93(0.78,1.10) \\
.40\end{array}$ & . 007 \\
\hline $\begin{array}{l}\text { Multivariable-adjusted HRs }(95 \% \text { CIs })^{\text {a,b }} \\
\text { p-value }\end{array}$ & 1 (reference) & $\begin{array}{c}2.99(1.21,7.38) \\
.018\end{array}$ & $\begin{array}{c}3.47(1.32,9.10) \\
.012\end{array}$ & .004 & $\begin{array}{c}1.46(1.13,1.88) \\
.004\end{array}$ & 1 (reference) & $\begin{array}{l}0.87(0.57,1.34) \\
\quad .54\end{array}$ & $\begin{array}{c}0.87(0.54,1.40) \\
.57\end{array}$ & .53 & $\begin{array}{c}0.93(0.78,1.12) \\
.45\end{array}$ & .010 \\
\hline \multicolumn{12}{|l|}{ Hemorrhagic stroke } \\
\hline No. of cases & 11 & 7 & 3 & & 21 & 17 & 31 & 13 & & 61 & \\
\hline $\begin{array}{l}\text { Age- and sex-adjusted HRs }(95 \% \mathrm{CIs})^{\mathrm{a}} \\
\text { p-value }\end{array}$ & 1 (reference) & $\begin{array}{c}0.81(0.29,2.23) \\
.68\end{array}$ & $\begin{array}{c}0.57(0.15,2.13) \\
.41\end{array}$ & .40 & $\begin{array}{c}0.79(0.52,1.21) \\
.28\end{array}$ & 1 (reference) & $\begin{array}{c}1.77(0.99,3.15) \\
.054\end{array}$ & $\begin{array}{c}1.07(0.53,2.18) \\
.84\end{array}$ & .67 & $\begin{array}{c}1.00(0.83,1.22) \\
.98\end{array}$ & . 097 \\
\hline $\begin{array}{l}\text { Multivariable-adjusted HRs }(95 \% \text { CIs })^{\text {a,b }} \\
\text { p-value }\end{array}$ & 1 (reference) & $\begin{array}{c}0.80(0.30,2.13) \\
.65\end{array}$ & $\begin{array}{c}0.55(0.15,2.04) \\
.37\end{array}$ & .37 & $\begin{array}{c}0.78(0.51,1.19) \\
.24\end{array}$ & 1 (reference) & $\begin{array}{c}1.73(0.97,3.07) \\
.062\end{array}$ & $\begin{array}{c}1.08(0.53,2.19) \\
.84\end{array}$ & .66 & $\begin{array}{c}1.00(0.82,1.23) \\
.97\end{array}$ & . 092 \\
\hline \multicolumn{12}{|l|}{ Ischemic cardiovascular disease } \\
\hline No. of cases & 11 & 25 & 18 & & 54 & 68 & 61 & 40 & & 169 & \\
\hline $\begin{array}{l}\text { Age- and sex-adjusted HRs }(95 \% \mathrm{CIs})^{\mathrm{a}} \\
\text { p-value }\end{array}$ & 1 (reference) & $\begin{array}{c}2.70(1.33,5.51) \\
.006\end{array}$ & $\begin{array}{c}2.90(1.36,6.21) \\
.006\end{array}$ & .002 & $\begin{array}{c}1.42(1.15,1.75) \\
.001\end{array}$ & 1 (reference) & $\begin{array}{c}0.94(0.66,1.33) \\
.71\end{array}$ & $\begin{array}{c}0.87(0.59,1.30) \\
.50\end{array}$ & .49 & $\begin{array}{c}0.91(0.78,1.07) \\
.25\end{array}$ & .002 \\
\hline $\begin{array}{l}\text { Multivariable-adjusted HRs }(95 \% \mathrm{CIs})^{\mathrm{a}, \mathrm{b}} \\
\text { p-value }\end{array}$ & 1 (reference) & $\begin{array}{c}2.82(1.38,5.77) \\
.005\end{array}$ & $\begin{array}{c}2.90(1.34,6.28) \\
.007\end{array}$ & .002 & $\begin{array}{c}1.41(1.14,1.74) \\
.002\end{array}$ & 1 (reference) & $\begin{array}{c}0.91(0.64,1.29) \\
.58\end{array}$ & $\begin{array}{c}0.88(0.59,1.31) \\
.53\end{array}$ & .51 & $\begin{array}{c}0.92(0.78,1.08) \\
.29\end{array}$ & .002 \\
\hline
\end{tabular}

Hazard ratios (HRs) and $95 \%$ confidence intervals $(95 \%$ CIs) obtained from Cox proportional hazards models.

b Adjusted for age, sex, smoking status, drinking status, body mass index, hypertension, diabetes mellitus, and hyperlipidemia. 
$\underline{\text { Supplementary Table } 1 \text { Baseline characteristics among urban and rural residents according to tertiles ( } \mathrm{T} \text { ) of anger-in and -out scores. }}$

\begin{tabular}{|c|c|c|c|c|c|c|c|c|}
\hline \multirow[b]{2}{*}{ Anger-in score } & \multicolumn{4}{|c|}{ Urban } & \multicolumn{4}{|c|}{ Rural } \\
\hline & $\begin{array}{c}\mathrm{T} 1 \\
\text { (Scores 8-10) } \\
\end{array}$ & $\begin{array}{c}\mathrm{T} 2 \\
\text { (Scores 11-14) } \\
\end{array}$ & $\begin{array}{c}\mathrm{T} 3 \\
\text { (Scores 15-29) } \\
\end{array}$ & $\mathrm{p}$ for trend ${ }^{\mathrm{a}}$ & $\begin{array}{c}\mathrm{T} 1 \\
\text { (Scores 8-10) } \\
\end{array}$ & $\begin{array}{c}\mathrm{T} 2 \\
\text { (Scores 11-14) } \\
\end{array}$ & $\begin{array}{c}\mathrm{T} 3 \\
\text { (Scores 15-31) } \\
\end{array}$ & $\mathrm{p}$ for trend ${ }^{\mathrm{a}}$ \\
\hline Number of participants & 561 & 739 & 577 & & 1014 & 1711 & 1334 & \\
\hline Age (year), mean (SD) & $61.4(9.3)$ & $57.2(9.4)$ & $56.5(8.7)$ & $<.001$ & $59.5(8.6)$ & $56.6(8.8)$ & $55.4(8.9)$ & $<.001$ \\
\hline Men, n (\%) & $177(31.6)$ & $214(29.0)$ & $169(29.3)$ & .41 & $420(41.4)$ & $635(37.1)$ & $539(40.4)$ & .78 \\
\hline Body mass index $\left(\mathrm{kg} / \mathrm{m}^{2}\right)$, mean (SD) & $23.1(3.1)$ & $22.9(2.9)$ & $22.9(2.9)$ & .36 & $23.5(3.1)$ & $23.7(3.3)$ & $23.6(3.0)$ & .55 \\
\hline Current smoking, n (\%) & $108(19.3)$ & $124(16.8)$ & $118(20.5)$ & .59 & $216(21.3)$ & $376(22.0)$ & $302(22.6)$ & .44 \\
\hline Current drinking, n (\%) & $193(34.4)$ & $261(35.3)$ & $194(33.6)$ & .78 & $349(34.4)$ & $597(34.9)$ & $506(37.9)$ & .066 \\
\hline Hypertension, $\mathrm{n}(\%)$ & $266(47.4)$ & $307(41.5)$ & $236(40.9)$ & .027 & $519(51.2)$ & $800(46.8)$ & $579(43.4)$ & $<.001$ \\
\hline Systolic blood pressure (mmHg), mean (SD) & $137.7(21.1)$ & $134.4(20.6)$ & $133.3(19.2)$ & $<.001$ & $136.8(19.7)$ & $134.4(20.6)$ & $132.6(19.0)$ & $<.001$ \\
\hline Diastolic blood pressure $(\mathrm{mmHg})$, mean $(\mathrm{SD})$ & $81.8(11.2)$ & $81.5(11.2)$ & $82.0(11.1)$ & .72 & $81.1(11.4)$ & $80.4(12.0)$ & $80.6(11.6)$ & .41 \\
\hline Use of antihypertensive medication, $n(\%)$ & $92(16.4)$ & $95(12.9)$ & $74(12.8)$ & .083 & $203(20.0)$ & $312(18.2)$ & $198(14.8)$ & .001 \\
\hline Diabetes mellitus, $\mathrm{n}(\%)$ & $26(4.6)$ & $29(3.9)$ & $22(3.8)$ & .49 & $52(5.1)$ & $99(5.8)$ & $55(4.1)$ & .21 \\
\hline Serum glucose during fasting $(\mathrm{mg} / \mathrm{dL})$, mean $(\mathrm{SD})$ & $101.7(18.7)$ & $99.1(17.7)$ & $99.5(18.7)$ & .13 & $100.2(18.7)$ & $99.6(23.2)$ & $98.1(13.7)$ & .24 \\
\hline Serum glucose during non-fasting $(\mathrm{mg} / \mathrm{dL})$, mean $(\mathrm{SD})$ & $101.3(32.2)$ & $101.3(23.3)$ & $99.5(30.9)$ & .52 & $115.1(40.0)$ & $114.1(39.5)$ & $112.0(38.2)$ & .072 \\
\hline Use of hypoglycemic medication, $\mathrm{n}(\%)$ & $9(1.6)$ & $9(1.2)$ & $13(2.3)$ & .39 & $29(2.9)$ & $39(2.3)$ & $26(2.0)$ & .15 \\
\hline Hyperlipidemia, n (\%) & $260(46.4)$ & $327(44.3)$ & $274(47.5)$ & .69 & $339(33.4)$ & $598(35.0)$ & $450(33.7)$ & .94 \\
\hline Serum total cholesterol $(\mathrm{mg} / \mathrm{dL})$, mean $(\mathrm{SD})$ & $216.6(37.1)$ & $215.6(33.7)$ & $215.8(36.2)$ & .69 & $204.7(34.2)$ & $204.2(35.9)$ & $204.7(35.6)$ & .98 \\
\hline Use of lipid-lowering medication, $\mathrm{n}(\%)$ & $31(5.5)$ & $34(4.6)$ & $34(5.9)$ & .78 & $49(4.8)$ & $100(5.8)$ & $58(4.4)$ & .49 \\
\hline Anger-out score & $\begin{array}{c}\mathrm{T} 1 \\
\text { (Scores 8-9) } \\
\end{array}$ & $\begin{array}{c}\mathrm{T} 2 \\
\text { (Scores 10-13) } \\
\end{array}$ & $\begin{array}{c}\mathrm{T} 3 \\
\text { (Scores 14-32) } \\
\end{array}$ & $\mathrm{p}$ for trend $\mathrm{a}^{\mathrm{a}}$ & $\begin{array}{c}\mathrm{T} 1 \\
\text { (Scores 8-9) } \\
\end{array}$ & $\begin{array}{c}\mathrm{T} 2 \\
\text { (Scores 10-13) }\end{array}$ & $\begin{array}{c}\mathrm{T} 3 \\
\text { (Scores 14-32) }\end{array}$ & $\mathrm{p}$ for trend ${ }^{\mathrm{a}}$ \\
\hline Number of participants & 563 & 885 & 429 & & 1329 & 1870 & 860 & \\
\hline Age (year), mean (SD) & $61.8(8.9)$ & $57.2(9.3)$ & $55.6(9.0)$ & $<.001$ & $59.5(8.7)$ & $56.1(8.6)$ & $54.7(9.0)$ & $<.001$ \\
\hline Men, n (\%) & $145(25.8)$ & $245(27.7)$ & $170(39.6)$ & $<.001$ & $446(33.6)$ & $700(37.4)$ & $448(52.1)$ & $<.001$ \\
\hline Body mass index $\left(\mathrm{kg} / \mathrm{m}^{2}\right)$, mean (SD) & $23.0(3.2)$ & $22.8(2.8)$ & $23.2(2.9)$ & .40 & $23.4(3.2)$ & $23.6(3.1)$ & $23.7(3.0)$ & .031 \\
\hline Current smoking, $\mathrm{n}(\%)$ & $91(16.2)$ & $144(16.3)$ & $115(26.8)$ & $<.001$ & $248(18.7)$ & $406(21.7)$ & $240(27.9)$ & $<.001$ \\
\hline Current drinking, $\mathrm{n}(\%)$ & $154(27.4)$ & $296(33.5)$ & $198(46.2)$ & $<.001$ & $377(28.4)$ & $655(35.0)$ & $420(48.8)$ & $<.001$ \\
\hline Hypertension, n (\%) & $288(51.2)$ & $352(39.8)$ & $169(39.4)$ & $<.001$ & $672(50.6)$ & $852(45.6)$ & $374(43.5)$ & .001 \\
\hline Systolic blood pressure (mmHg), mean (SD) & $137.9(21.2)$ & $134.2(20.2)$ & $132.9(19.4)$ & $<.001$ & $135.5(20.3)$ & $134.1(19.5)$ & $133.5(20.4)$ & 016 \\
\hline Diastolic blood pressure (mmHg), mean (SD) & $81.7(11.2)$ & $81.6(11.2)$ & $82.1(11.1)$ & .59 & $79.9(11.7)$ & $80.8(11.6)$ & $81.4(12.1)$ & .003 \\
\hline Use of antihypertensive medication, $n(\%)$ & $99(17.6)$ & $104(11.8)$ & $58(13.5)$ & .039 & $290(21.8)$ & $305(16.3)$ & $118(13.7)$ & $<.001$ \\
\hline Diabetes mellitus, $\mathrm{n}(\%)$ & $27(4.8)$ & $27(3.1)$ & $23(5.4)$ & .81 & $67(5.0)$ & $93(5.0)$ & $46(5.4)$ & .78 \\
\hline Serum glucose during fasting $(\mathrm{mg} / \mathrm{dL})$, mean $(\mathrm{SD})$ & $101.8(20.7)$ & $98.7(18.2)$ & $100.1(14.9)$ & .18 & $101.1(21.8)$ & $98.5(20.1)$ & $98.2(13.1)$ & .16 \\
\hline Serum glucose during non-fasting $(\mathrm{mg} / \mathrm{dL})$, mean $(\mathrm{SD})$ & $99.5(24.9)$ & $99.1(17.3)$ & $106.0(46.6)$ & .039 & $114.2(40.1)$ & $112.9(37.6)$ & $114.7(41.1)$ & .98 \\
\hline Use of hypoglycemic medication, $\mathrm{n}(\%)$ & $12(2.1)$ & $11(1.2)$ & $8(1.9)$ & .66 & $29(2.2)$ & $44(2.4)$ & $21(2.4)$ & .68 \\
\hline Hyperlipidemia, n (\%) & $269(47.8)$ & $409(46.2)$ & $183(42.7)$ & .12 & $472(35.5)$ & $653(34.9)$ & $262(30.5)$ & .023 \\
\hline Serum total cholesterol $(\mathrm{mg} / \mathrm{dL})$, mean $(\mathrm{SD})$ & $217.8(34.8)$ & $215.2(35.5)$ & $215.2(36.4)$ & .22 & $206.8(35.0)$ & $204.6(35.4)$ & $200.5(35.6)$ & $<.001$ \\
\hline Use of lipid-lowering medication, $\mathrm{n}(\%)$ & $32(5.7)$ & $49(5.5)$ & $18(4.2)$ & .32 & $80(6.0)$ & $92(4.9)$ & $35(4.1)$ & .038 \\
\hline
\end{tabular}

abtained from linar regession analyses. 


\begin{tabular}{|c|c|c|c|c|c|c|c|c|c|c|c|}
\hline & \multicolumn{5}{|c|}{ Urban } & \multicolumn{5}{|c|}{ Rural } & \multirow[b]{2}{*}{$\mathrm{p}$ for interaction ${ }^{\mathrm{C}}$} \\
\hline & $\begin{array}{c}\mathrm{T} 1 \\
\text { (Scores 8-10) }\end{array}$ & $\begin{array}{c}\mathrm{T} 2 \\
\text { (Scores 11-14) }\end{array}$ & $\begin{array}{c}\mathrm{T} 3 \\
\text { (Scores 15-29) }\end{array}$ & $\mathrm{p}$ for trend & 1-SD increment & $\begin{array}{c}\mathrm{T} 1 \\
\text { (Scores 8-10) }\end{array}$ & $\begin{array}{c}\mathrm{T} 2 \\
\text { (Scores 11-14) }\end{array}$ & $\begin{array}{c}\mathrm{T} 3 \\
\text { (Scores 15-31) }\end{array}$ & $\mathrm{p}$ for trend & 1-SD increment & \\
\hline Person-years & 8920 & 12144 & 9485 & & 30549 & 14205 & 24588 & 19843 & & 58636 & \\
\hline \multicolumn{12}{|l|}{ Total cardiovascular disease } \\
\hline No. of cases & 20 & 31 & 25 & & 76 & 69 & 101 & 66 & & 236 & \\
\hline $\begin{array}{l}\text { Age- and sex-adjusted HRs }(95 \% \text { CIs })^{\text {a }} \\
\text { p-value }\end{array}$ & 1 (reference) & $\begin{array}{c}1.66(0.94,2.94) \\
.083\end{array}$ & $\begin{array}{c}1.90(1.04,3.49) \\
.037\end{array}$ & .030 & $\begin{array}{c}1.14(0.94,1.38) \\
.18\end{array}$ & 1 (reference) & $\begin{array}{c}1.09(0.80,1.48) \\
.58\end{array}$ & $\begin{array}{c}0.91(0.65,1.28) \\
.59\end{array}$ & .58 & $\begin{array}{c}0.96(0.84,1.09) \\
.49\end{array}$ & 19 \\
\hline $\begin{array}{l}\text { Multivariable-adjusted HRs }(95 \% \mathrm{CIs})^{\mathrm{a}, \mathrm{b}} \\
\text { p-value }\end{array}$ & 1 (reference) & $\begin{array}{c}1.63(0.91,2.92) \\
.10\end{array}$ & $\begin{array}{c}1.90(1.03,3.49) \\
.039\end{array}$ & .032 & $\begin{array}{c}1.13(0.93,1.37) \\
.22\end{array}$ & 1 (reference) & $\begin{array}{c}1.05(0.77,1.43) \\
.77\end{array}$ & $\begin{array}{c}0.91(0.65,1.28) \\
.59\end{array}$ & .58 & $\begin{array}{c}0.96(0.84,1.09) \\
.51\end{array}$ & .21 \\
\hline \multicolumn{12}{|l|}{ Ischemic heart disease } \\
\hline No. of cases & 4 & 6 & 10 & & 20 & 15 & 26 & 11 & & 52 & \\
\hline $\begin{array}{l}\text { Age- and sex-adjusted HRs }(95 \% \mathrm{CIs})^{\mathrm{a}} \\
\text { p-value }\end{array}$ & 1 (reference) & $\begin{array}{c}1.41(0.41,4.87) \\
.58\end{array}$ & $\begin{array}{c}3.18(1.00,10.10) \\
.050\end{array}$ & .048 & $\begin{array}{c}1.21(0.89,1.65) \\
.22\end{array}$ & 1 (reference) & $\begin{array}{c}1.28(0.68,2.38) \\
.45\end{array}$ & $\begin{array}{c}0.66(0.30,1.47) \\
.31\end{array}$ & .28 & $\begin{array}{c}0.87(0.64,1.20) \\
.40\end{array}$ & .11 \\
\hline $\begin{array}{l}\text { Multivariable-adjusted HRs }(95 \% \text { CIs })^{\text {a,b }} \\
\text { p-value }\end{array}$ & 1 (reference) & $\begin{array}{l}1.28(0.36,4.54) \\
\quad .71\end{array}$ & $\begin{array}{c}3.05(0.93,10.04) \\
\quad .066\end{array}$ & .064 & $\begin{array}{c}1.20(0.85,1.69) \\
.31\end{array}$ & 1 (reference) & $\begin{array}{c}1.17(0.62,2.21) \\
.63\end{array}$ & $\begin{array}{c}0.64(0.29,1.43) \\
.28\end{array}$ & .25 & $\begin{array}{c}0.86(0.61,1.20) \\
.38\end{array}$ & .12 \\
\hline \multicolumn{12}{|l|}{ Total stroke } \\
\hline No. of cases & 16 & 25 & 15 & & 56 & 54 & 75 & 55 & & 184 & \\
\hline $\begin{array}{l}\text { Age- and sex-adjusted HRs }(95 \% \mathrm{CIs})^{\mathrm{a}} \\
\text { p-value }\end{array}$ & 1 (reference) & $\begin{array}{c}1.75(0.92,3.34) \\
.090\end{array}$ & $\begin{array}{c}1.52(0.73,3.15) \\
.27\end{array}$ & .20 & $\begin{array}{c}1.11(0.88,1.40) \\
.38\end{array}$ & 1 (reference) & $\begin{array}{c}1.04(0.73,1.48) \\
.84\end{array}$ & $\begin{array}{c}0.98(0.67,1.44) \\
.93\end{array}$ & .93 & $\begin{array}{c}0.98(0.85,1.13) \\
.77\end{array}$ & .54 \\
\hline $\begin{array}{l}\text { Multivariable-adjusted HRs }(95 \% \text { CIs })^{\text {a,b }} \\
\text { p-value }\end{array}$ & 1 (reference) & $\begin{array}{c}1.75(0.90,3.43) \\
.10\end{array}$ & $\begin{array}{c}1.52(0.73,3.18) \\
.27\end{array}$ & .20 & $\begin{array}{c}1.10(0.87,1.38) \\
.44\end{array}$ & 1 (reference) & $\begin{array}{c}1.01(0.70,1.44) \\
.97\end{array}$ & $\begin{array}{c}0.99(0.67,1.44) \\
.94\end{array}$ & .94 & $\begin{array}{c}0.98(0.85,1.13) \\
.80\end{array}$ & .58 \\
\hline \multicolumn{12}{|l|}{ Ischemic stroke } \\
\hline No. of cases & 8 & 15 & 11 & & 34 & 37 & 48 & 32 & & 117 & \\
\hline $\begin{array}{l}\text { Age- and sex-adjusted HRs }(95 \% \mathrm{CIs})^{\mathrm{a}} \\
\text { p-value }\end{array}$ & 1 (reference) & $\begin{array}{c}2.11(0.88,5.04) \\
.093\end{array}$ & $\begin{array}{c}2.28(0.90,5.79) \\
.083\end{array}$ & .060 & $\begin{array}{c}1.28(0.96,1.70) \\
.088\end{array}$ & 1 (reference) & $\begin{array}{c}1.00(0.65,1.54) \\
\quad>.99\end{array}$ & $\begin{array}{c}0.86(0.54,1.39) \\
.55\end{array}$ & .55 & $\begin{array}{c}0.94(0.78,1.13) \\
.50\end{array}$ & 10 \\
\hline $\begin{array}{l}\text { Multivariable-adjusted HRs }(95 \% \mathrm{CIs})^{\text {a,b }} \\
\text { p-value }\end{array}$ & 1 (reference) & $\begin{array}{c}2.24(0.90,5.59) \\
.084\end{array}$ & $\begin{array}{c}2.37(0.91,6.13) \\
.076\end{array}$ & .051 & $\begin{array}{c}1.28(0.97,1.68) \\
.081\end{array}$ & 1 (reference) & $\begin{array}{c}0.96(0.62,1.49) \\
.87\end{array}$ & $\begin{array}{c}0.87(0.54,1.40) \\
\quad .56\end{array}$ & .56 & $\begin{array}{c}0.94(0.78,1.13) \\
.52\end{array}$ & .12 \\
\hline \multicolumn{12}{|l|}{ Hemorhagic stroke } \\
\hline No. of cases & 8 & 10 & 3 & & 21 & 15 & 26 & 20 & & 61 & \\
\hline $\begin{array}{l}\text { Age- and sex-adjusted HRs }(95 \% \mathrm{CIs})^{\mathrm{a}} \\
\text { p-value }\end{array}$ & 1 (reference) & $\begin{array}{c}1.37(0.50,3.77) \\
.54\end{array}$ & $\begin{array}{l}0.58(0.15,2.31) \\
\quad .44\end{array}$ & .54 & $\begin{array}{c}0.76(0.51,1.14) \\
.19\end{array}$ & 1 (reference) & $\begin{array}{c}1.20(0.63,2.31) \\
.58\end{array}$ & $\begin{array}{l}1.18(0.60,2.35) \\
.63\end{array}$ & .64 & $\begin{array}{c}1.03(0.82,1.29) \\
.81\end{array}$ & .10 \\
\hline $\begin{array}{l}\text { Multivariable-adjusted HRs }(95 \% \text { CIs })^{\text {a,b }} \\
\text { p-value }\end{array}$ & 1 (reference) & $\begin{array}{c}1.30(0.47,3.61) \\
.61\end{array}$ & $\begin{array}{l}0.58(0.15,2.27) \\
.43\end{array}$ & .52 & $\begin{array}{c}0.75(0.50,1.13) \\
.16\end{array}$ & 1 (reference) & $\begin{array}{l}1.19(0.62,2.28) \\
.61\end{array}$ & $\begin{array}{l}1.18(0.60,2.36) \\
.63\end{array}$ & .64 & $\begin{array}{c}1.03(0.82,1.30) \\
.80\end{array}$ & .094 \\
\hline \multicolumn{12}{|l|}{ Ischemic cardiovascular disease } \\
\hline No. of cases & 12 & 21 & 21 & & 54 & 52 & 74 & 43 & & 169 & \\
\hline $\begin{array}{l}\text { Age- and sex-adjusted HRs }(95 \% \mathrm{CIs})^{\mathrm{a}} \\
\text { p-value }\end{array}$ & 1 (reference) & $\begin{array}{c}1.86(0.91,3.78) \\
.088\end{array}$ & $\begin{array}{c}2.66(1.29,5.47) \\
.008\end{array}$ & .006 & $\begin{array}{c}1.26(1.02,1.56) \\
.036\end{array}$ & 1 (reference) & $\begin{array}{c}1.08(0.76,1.54) \\
\quad .66\end{array}$ & $\begin{array}{c}0.80(0.53,1.21) \\
.29\end{array}$ & .28 & $\begin{array}{c}0.92(0.79,1.08) \\
.30\end{array}$ & .024 \\
\hline $\begin{array}{l}\text { Multivariable-adjusted HRs }\left(95 \% \text { CIss }{ }^{\text {a,b }}\right. \\
\text { p-value }\end{array}$ & 1 (reference) & $\begin{array}{c}1.85(0.89,3.84) \\
.10\end{array}$ & $\begin{array}{c}2.65(1.27,5.50) \\
.009\end{array}$ & . 007 & $\begin{array}{l}1.25(1.01,1.55) \\
.043\end{array}$ & 1 (reference) & $\begin{array}{c}1.03(0.72,1.47) \\
.87\end{array}$ & $\begin{array}{c}0.80(0.53,1.21) \\
.29\end{array}$ & .28 & $\begin{array}{c}0.92(0.78,1.08) \\
.31\end{array}$ & .027 \\
\hline
\end{tabular}

atazard ratios (HRs) and $95 \%$ confidence intervals $(95 \%$ CIs) obtained from Cox proportional hazards models.

b Adjusted for age, sex, smoking status, drinking status, body mass index, hypertension, diabetes mellitus, and hyperlipidemia. 


\begin{tabular}{|c|c|c|c|c|c|c|c|c|c|c|c|}
\hline & \multicolumn{5}{|c|}{ Urban } & \multicolumn{5}{|c|}{ Rural } & \multirow[b]{2}{*}{$\mathrm{p}$ for interaction ${ }^{\mathrm{C}}$} \\
\hline & $\begin{array}{c}\mathrm{T} 1 \\
\text { (Scores 8-9) }\end{array}$ & $\begin{array}{c}\mathrm{T} 2 \\
\text { (Scores 10-13) }\end{array}$ & $\begin{array}{c}\mathrm{T3} \\
\text { (Scores 14-32) }\end{array}$ & $\mathrm{p}$ for trend & 1-SD increment & $\begin{array}{c}\mathrm{T} 1 \\
\text { (Scores 8-9) }\end{array}$ & $\begin{array}{c}\mathrm{T} 2 \\
\text { (Scores 10-13) }\end{array}$ & $\begin{array}{c}\mathrm{T} 3 \\
\text { (Scores 14-32) }\end{array}$ & $\mathrm{p}$ for trend & 1-SD increment & \\
\hline Person-years & 9000 & 14525 & 7024 & & 30549 & 18655 & 27348 & 12634 & & 58636 & \\
\hline \multicolumn{12}{|l|}{ Total cardiovascular disease } \\
\hline No. of cases & 24 & 31 & 21 & & 76 & 88 & 104 & 44 & & 236 & \\
\hline $\begin{array}{l}\text { Age- and sex-adjusted HRs }(95 \% \text { CIs })^{\text {a }} \\
\text { p-value }\end{array}$ & 1 (reference) & $\begin{array}{c}1.17(0.68,2.04) \\
.57\end{array}$ & $\begin{array}{c}1.85(1.01,3.37) \\
.047\end{array}$ & .064 & $\begin{array}{c}1.28(1.07,1.53) \\
.007\end{array}$ & 1 (reference) & $\begin{array}{c}0.99(0.74,1.32) \\
.95\end{array}$ & $\begin{array}{c}0.90(0.62,1.30) \\
.57\end{array}$ & .61 & $\begin{array}{c}0.97(0.85,1.10) \\
.61\end{array}$ & .043 \\
\hline $\begin{array}{l}\text { Multivariable-adjusted HRs }(95 \% \mathrm{CIs})^{\mathrm{a}, \mathrm{b}} \\
\text { p-value }\end{array}$ & 1 (reference) & $\begin{array}{c}1.20(0.70,2.07) \\
.51\end{array}$ & $\begin{array}{c}1.89(1.04,3.43) \\
.038\end{array}$ & .051 & $\begin{array}{c}1.28(1.07,1.53) \\
.006\end{array}$ & 1 (reference) & $\begin{array}{c}1.00(0.75,1.33) \\
.97\end{array}$ & $\begin{array}{c}0.92(0.63,1.33) \\
.66\end{array}$ & 69 & $\begin{array}{c}0.97(0.85,1.11) \\
.70\end{array}$ & .055 \\
\hline \multicolumn{12}{|l|}{ Ischemic heart disease } \\
\hline No. of cases & 8 & 5 & 7 & & 20 & 18 & 25 & 9 & & 52 & \\
\hline $\begin{array}{l}\text { Age- and sex-adjusted HRs }(95 \% \mathrm{CIs})^{\mathrm{a}} \\
\text { p-value }\end{array}$ & 1 (reference) & $\begin{array}{c}0.48(0.15,1.51) \\
.21\end{array}$ & $\begin{array}{c}1.37(0.49,3.80) \\
.55\end{array}$ & .70 & $\begin{array}{c}1.33(0.91,1.96) \\
.15\end{array}$ & 1 (reference) & $\begin{array}{c}1.08(0.58,2.03) \\
.81\end{array}$ & $\begin{array}{c}0.75(0.33,1.72) \\
.50\end{array}$ & .56 & $\begin{array}{c}0.91(0.66,1.26) \\
.58\end{array}$ & .20 \\
\hline $\begin{array}{l}\text { Multivariable-adjusted HRs }(95 \% \text { CIs })^{\text {a,b }} \\
\text { p-value }\end{array}$ & 1 (reference) & $\begin{array}{c}0.48(0.16,1.50) \\
.21\end{array}$ & $\begin{array}{c}1.39(0.50,3.89) \\
.53\end{array}$ & .70 & $\begin{array}{c}1.28(0.85,1.91) \\
.23\end{array}$ & 1 (reference) & $\begin{array}{c}1.08(0.57,2.06) \\
.81\end{array}$ & $\begin{array}{c}0.79(0.34,1.81) \\
.57\end{array}$ & .64 & $\begin{array}{c}0.92(0.67,1.28) \\
.64\end{array}$ & .27 \\
\hline \multicolumn{12}{|l|}{ Total stroke } \\
\hline No. of cases & 16 & 26 & 14 & & 56 & 70 & 79 & 35 & & 184 & \\
\hline $\begin{array}{l}\text { Age- and sex-adjusted HRs }(95 \% \mathrm{CIs})^{a} \\
\text { p-value }\end{array}$ & 1 (reference) & $\begin{array}{c}1.56(0.82,2.96) \\
.17\end{array}$ & $\begin{array}{c}2.03(0.97,4.25) \\
.060\end{array}$ & .049 & $\begin{array}{c}1.26(1.04,1.53) \\
.019\end{array}$ & 1 (reference) & $\begin{array}{l}0.97(0.70,1.34) \\
\quad .84\end{array}$ & $\begin{array}{c}0.95(0.63,1.43) \\
.79\end{array}$ & .78 & $\begin{array}{c}0.98(0.85,1.13) \\
.81\end{array}$ & 12 \\
\hline $\begin{array}{l}\text { Multivariable-adjusted HRs }(95 \% \text { CIs })^{\text {a,b }} \\
\text { p-value }\end{array}$ & 1 (reference) & $\begin{array}{c}1.60(0.85,3.03) \\
.15\end{array}$ & $\begin{array}{c}2.10(1.01,4.36) \\
\quad .047\end{array}$ & .037 & $\begin{array}{c}1.27(1.05,1.55) \\
.016\end{array}$ & 1 (reference) & $\begin{array}{c}0.97(0.70,1.34) \\
.85\end{array}$ & $\begin{array}{c}0.96(0.64,1.46) \\
.86\end{array}$ & .84 & $\begin{array}{c}0.99(0.86,1.14) \\
.88\end{array}$ & .14 \\
\hline \multicolumn{12}{|l|}{ Ischemic stroke } \\
\hline No. of cases & 11 & 11 & 12 & & 34 & 46 & 51 & 20 & & 117 & \\
\hline $\begin{array}{l}\text { Age- and sex-adjusted HRs }(95 \% \mathrm{CIs})^{\mathrm{a}} \\
\text { p-value }\end{array}$ & 1 (reference) & $\begin{array}{c}0.91(0.39,2.13) \\
.82\end{array}$ & $\begin{array}{c}2.24(0.96,5.20) \\
.061\end{array}$ & .11 & $\begin{array}{c}1.37(1.11,1.70) \\
.004\end{array}$ & 1 (reference) & $\begin{array}{c}0.98(0.65,1.46) \\
.90\end{array}$ & $\begin{array}{c}0.84(0.49,1.42) \\
.51\end{array}$ & .54 & $\begin{array}{c}0.93(0.78,1.11) \\
.42\end{array}$ & .006 \\
\hline $\begin{array}{l}\text { Multivariable-adjusted HRs }(95 \% \mathrm{CIs})^{\text {a,b }} \\
\text { p-value }\end{array}$ & 1 (reference) & $\begin{array}{c}0.93(0.40,2.14) \\
.86\end{array}$ & $\begin{array}{c}2.36(1.01,5.51) \\
.047\end{array}$ & .091 & $\begin{array}{c}1.38(1.10,1.74) \\
.006\end{array}$ & 1 (reference) & $\begin{array}{c}0.99(0.66,1.48) \\
.94\end{array}$ & $\begin{array}{l}0.86(0.51,1.47) \\
.59\end{array}$ & .62 & $\begin{array}{c}0.94(0.79,1.12) \\
.50\end{array}$ & .010 \\
\hline \multicolumn{12}{|l|}{ Hemorhagic stroke } \\
\hline No. of cases & 5 & 14 & 2 & & 21 & 23 & 26 & 12 & & 61 & \\
\hline $\begin{array}{l}\text { Age- and sex-adjusted HRs }(95 \% \mathrm{CIs})^{\mathrm{a}} \\
\text { p-value }\end{array}$ & 1 (reference) & $\begin{array}{l}2.89(1.01,8.25) \\
.048\end{array}$ & $\begin{array}{c}1.13(0.21,6.08) \\
.89\end{array}$ & .31 & $\begin{array}{c}0.94(0.64,1.37) \\
.73\end{array}$ & 1 (reference) & $\begin{array}{l}0.90(0.52,1.57) \\
.72\end{array}$ & $\begin{array}{c}0.92(0.45,1.91) \\
.83\end{array}$ & .79 & $\begin{array}{c}0.97(0.75,1.25) \\
\quad .81\end{array}$ & .31 \\
\hline $\begin{array}{l}\text { Multivariable-adjusted HRs }(95 \% \text { CIs })^{\text {a,b }} \\
\text { p-value }\end{array}$ & 1 (reference) & $\begin{array}{l}.997(1.04,8.49) \\
.042\end{array}$ & $\begin{array}{c}1.09(0.20,5.94) \\
.92\end{array}$ & .33 & $\begin{array}{c}0.92(0.63,1.36) \\
.69\end{array}$ & 1 (reference) & $\begin{array}{l}0.89(0.51,1.55) \\
.69\end{array}$ & $\begin{array}{c}0.92(0.44,1.91) \\
.83\end{array}$ & .78 & $\begin{array}{l}0.97(0.75,1.26) \\
.83\end{array}$ & .32 \\
\hline \multicolumn{12}{|l|}{ Ischemic cardiovascular disease } \\
\hline No. of cases & 19 & 16 & 19 & & 54 & 64 & 76 & 29 & & 169 & \\
\hline $\begin{array}{l}\text { Age- and sex-adjusted HRs }(95 \% \mathrm{CIs})^{\mathrm{a}} \\
\text { p-value }\end{array}$ & 1 (reference) & $\begin{array}{c}0.73(0.37,1.45) \\
.37\end{array}$ & $\begin{array}{c}1.89(0.98,3.63) \\
.058\end{array}$ & .13 & $\begin{array}{c}1.35(1.12,1.64) \\
.002\end{array}$ & 1 (reference) & $\begin{array}{c}1.00(0.72,1.41) \\
.98\end{array}$ & $\begin{array}{c}0.81(0.52,1.26) \\
.35\end{array}$ & .40 & $\begin{array}{c}0.92(0.79,1.08) \\
.33\end{array}$ & .004 \\
\hline $\begin{array}{l}\text { Multivariable-adjusted HRs }\left(95 \% \text { CIss }{ }^{\text {a,b }}\right. \\
\text { p-value }\end{array}$ & 1 (reference) & $\begin{array}{c}0.75(0.38,1.47) \\
.40\end{array}$ & $\begin{array}{c}1.94(1.01,3.74) \\
.047\end{array}$ & .11 & $\begin{array}{c}1.35(1.11,1.65) \\
.003\end{array}$ & 1 (reference) & $\begin{array}{c}1.01(0.72,1.43) \\
.94\end{array}$ & $\begin{array}{c}0.83(0.53,1.31) \\
.43\end{array}$ & .50 & $\begin{array}{c}0.93(0.79,1.10) \\
.41\end{array}$ & .007 \\
\hline
\end{tabular}

a Hazard ratios (HRs) and $95 \%$ confidence intervals $(95 \%$ CIs) obtained from Cox proportional hazards models.

b Adjusted for age, sex, smoking status, drinking status, body mass index, hypertension, diabetes mellitus, and hyperlipidemia. 